\title{
HAS YOUR STATE SUFFICIENT JUDGES?
}

To call a person "Judge," in the hearing of the average American citizen, especially if he be of an inquiring mind, is usually to invite the question, "Of what court is he judge?" and the further inquiry whether his court can hang a man or send him to the State Penitentiary, or whether it can deprive a citizen of his property? Some one has humorously observed that the judges of the past generation were usually severe and stern men, who "believed in hanging, hell fire and castor oil." The judges of the appellate courts are likewise respected by all, but in them, dealing only in questions of law on appeal, the citizens do not take the same interest as they do in those judges whose everyday work in the course of the year, brings them in elbow touch with all grades, classes and conditions of our people.

It is, therefore, to the so-called trial judges, or, to properly designate them, the judges of the courts of general jurisdiction; that the inquiry, which is the title of this article, refers, and to the solution of which inquiry no universal rule can be laid down for every State. But the experience, whether satisfactory or not, of each State can help others in its solution.

All will agree with the plain statement that there should be provided a sufficient number of judges to properly transact the business of the courts, both civil and criminal. Yet what is a sufficient number to transact that business is a matter about which people can, and will conscientiously, differ, as each one will not have the same facts before him; and men of practical judgment: decide matters with the light before them as they see it.

In these days of muckraking writers, inflaming the mind against a calm and deliberate consideration of public matters, it it often-times difficult to arrive at the facts concerning any public question. It is popular today to cry against the "Law's Delay," and generally to condemn the judicial system of America, some few going so far as to advocate recall of all public officials. (Judges included), and that an absolute present-day majority rule (whose sympathies may change over night) be substituted for our system of representative government by the people, in which the minority is protected in its rights against oppression 
by the majority, while the majority is given free rein to pass and enforce any law that does not override the fundamental law made by the people for their government and protection.

For the "Law's Delay" the writer (a lawyer) has no excuse to make, nor apology to offer. In numerous cases it exists; in the large majority of instances it can, and should be, corrected; and the means of correction, almost without exception, are within the power of the law-making body of each State, and can easily be provided. The scope of this article, and its broad subject, precludes discussing such delays as are incident to legal procedure, professional courtesy, appeal and error, expensive litigation, and long-protracted trials, yet later on the article will call attention to one fruitful source of the'law's delay, especially in the larger cities and the older and more populous States east of the Mississippi river.

It is easy to find fault with and condemn an existing condition that does not in every way meet popular approval. That is the especial privilege of the demagogue and fault finder, and almost the sole financial support and livelihood of the muckraking writer and lecturer.

The people justly honor, respect and follow one who not only points out defects in existing present-day affairs, but also suggests a practical remedy in each instance by which the people themselves may better the objectionable conditions. Therein lies the difference between a statesman or political economist on the one hand, and a demagogue or fault-finder on the other. The American people always try to be fair in deciding questions and their sober second thought, their deliberate judgment, is always better than the impulse of the moment.

What is a court of general jurisdiction, and how small a case can it try? The jurisdiction varies from any amount howsoever small in Maine, New Hampshire, New Jersey, New York, Oregon, Pennsylvania and Utah, to $\$ 500$ in Connecticut, Rhode Island and Texas. It is $\$ 20$ in Virginia; $\$ 50$ in Alabama, Alaska, Delaware, Hawaii, Kentucky, Louisiana, Maryland, Montana, Tennessee and West Virginia; $\$ 100$ in Arizona, Arkansas, District of Columbia, Florida, Georgia, Iowa, Massachusetts, Michigan, Minnesota, New Mexico, Ohio, South Carolina, South Dakota and Washington; $\$ 200$ in Illinois, Indiana, Mississippi, 
Nebraska, North Carolina, North Dakota, Oklahoma, Vermont, Wisconsin and Wyoming; $\$ 250$ in Missouri ; \$300 in California, Colorado, Idaho, Kansas and Nevada, and, as above stated, $\$ 500$ in Connecticut, Rhode Island and Texas. It is noticeable that nearly one-third have the $\$ 100$ minimum, and nineteen have a greater, while eighteen has a lesser sum, to confer jurisdiction.

The attached table (Table I) shows the population and the number of trial judges in the several states (including territories) and the proportion of population to each judge:

TABLE I.

\begin{tabular}{|c|c|c|c|c|c|c|c|c|}
\hline Alabama...$\ldots \ldots$ & 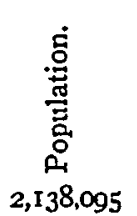 & 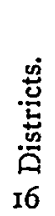 & 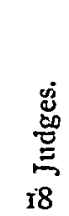 & $\begin{array}{l}\stackrel{\infty}{ \pm 0} \\
\stackrel{0}{0} \\
\dot{0} \\
5\end{array}$ & 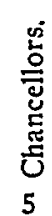 & 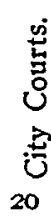 & 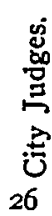 & 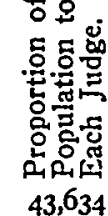 \\
\hline Arizona...$\ldots \ldots$ & 204,354 & 5 & 5 & & & & & 40,871 \\
\hline Arkansas $\ldots \ldots \ldots$ & $I, 574,449$ & I7 & 17 & I2 & $\mathrm{I} 2$ & & & $54,29 \mathrm{I}$ \\
\hline California ........ & $2,377,549$ & 58 & roo & & & & & 23,775 \\
\hline Colorado .......... & 799,024 & 13 & 2I & & & & & 38,049 \\
\hline Connecticut $\ldots . .$. . & $1,114,756$ & - & 12 & & & $\mathbf{5}$ & 5 & 3,422 \\
\hline Delaware ......... & 202,322 & 一 & 5 & I & I & & & 33,720 \\
\hline Dist. of Col. ....... & 331,069 & 一 & 6 & & 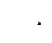 & & & 55,178 \\
\hline Florida ........... & 751,139 & I I & II & & & & & 68.285 \\
\hline Georgia........ & $2,609,121$ & 27 & 29 & & & 78 & 79 & 24,158 \\
\hline Idaho.......... & 325,594 & 9 & 12 & & & & & 27,133 \\
\hline Illinois........ & $5,638,591$ & 18 & 66 & & & 23 & 39 & 53,701 \\
\hline Indiana $\quad . . . \ldots \ldots$. & $2,700,8,6$ & 63 & 63 & & & II & 18 & 33,332 \\
\hline Iowa $. . . \ldots \ldots \ldots . .$. & $2,224,771$ & 20 & 56 & & & & & $39,37 \mathrm{I}$ \\
\hline Kansas ........... & $1,690,940$ & 38 & $4 I$ & & & & & 41,242 \\
\hline Kentucky ......... & $2,289,905$ & 34 & 40 & & & & & 57,248 \\
\hline Louisiana $. . . \ldots .$. & $1,656,388$ & 30 & 35 & & & & & 47,325 \\
\hline Maine.......... & 742,371 & 一 & 8 & & & 2 & 2 & 74,237 \\
\hline Maryland $. . . \ldots .$. & $I, 295,346$ & 8 & $3 I$ & & & & & 41,785 \\
\hline Massachusetts ,... & $3,366,416$ & 一 & 28 & & & & & 120,229 \\
\hline Michigan ........ & $2,810,173$ & 39 & 50 & & & & & 56,203 \\
\hline Minnesota ....... & $2,075,708$ & I9 & 40 & & & & & 51,892 \\
\hline Mississippi $\quad . . . .$. & $I, 797, I_{4} 4$ & 17 & 17 & Io & To & & & 66,559 \\
\hline Missouri .......... & $3,293,335$ & 36 & 59 & & & & & 55,819 \\
\hline Montana .......... & 376,053 & 13 & $2 I$ & & & & & 17,907 \\
\hline Nebraska ......... & $I, I 92,214$ & 16 & 29 & & & & & $4 \mathrm{I}, \mathrm{III}$ \\
\hline Nevada .......... & 81,875 & 9 & 10 & & & & & 8,187 \\
\hline New Hampshire .. & 430,572 & - & 5 & & & & & $86, \mathrm{ri}_{4}$ \\
\hline New Jersey ....... & $2,537,167$ & 9 & 16 & - & 8 & & & 105,715 \\
\hline New Mexico ...... & 327,301 & 8 & 8 & & & & & 40,912 \\
\hline New York ......... & $9,113,279$ & I9 & 102 & & & & & 89,324 \\
\hline North Carolina ... & $2,206,287$ & I6 & 16 & & & & & \\
\hline
\end{tabular}




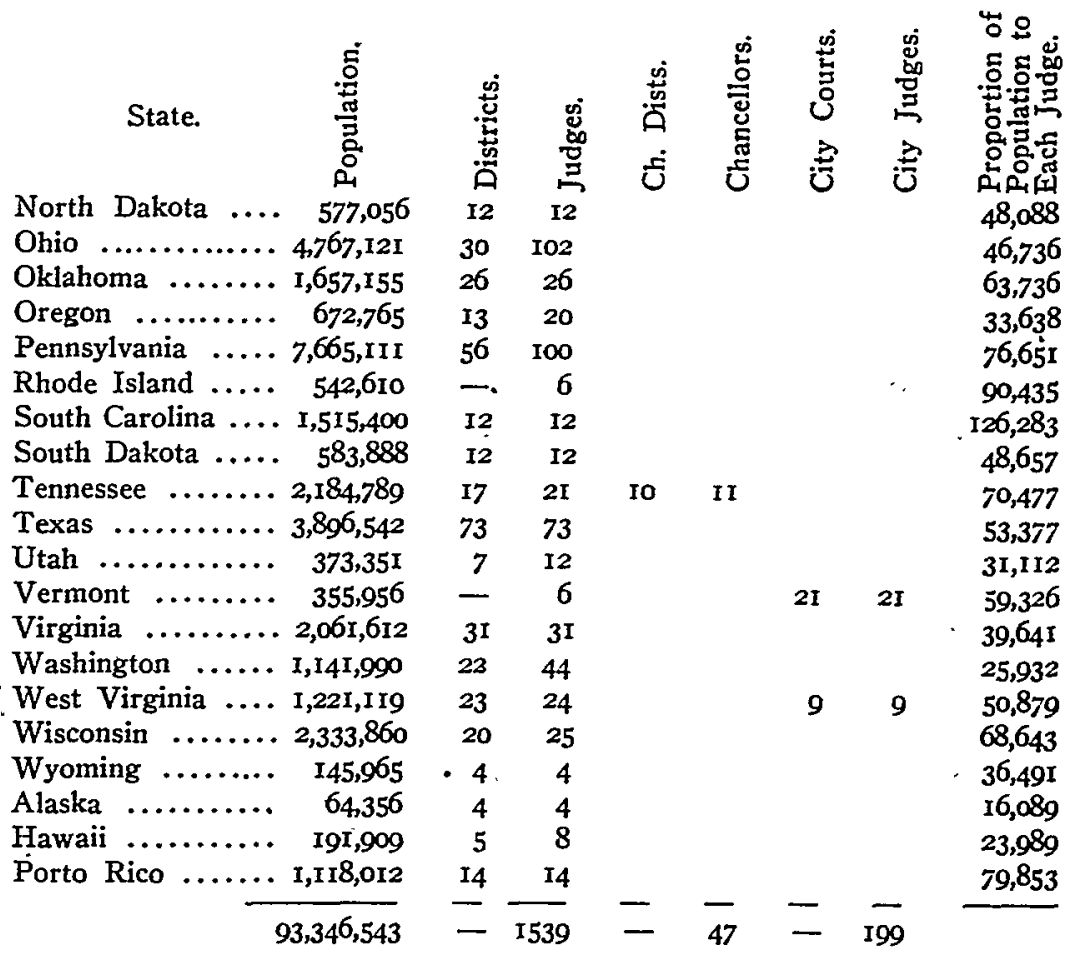

The total number of judges of general jurisdiction is 1,785 , or an average of one for each 52,295 of population. If Alaska, Hawaii and Porto Rico be omitted the result is practically the same, or an average of one for each 52,287 .

Of the fifty-two States and Territories it will be seen that forty have a single class of judges, who are designated as judges of courts by various names, some of which are Common Pleas (Pennsylvania and Ohio), Supreme Court (New York), District Court (California, Louisiana and Texas), Circuit Court (Missouri) and Superior Court (North Carolina).

Six States (Alabama, Arkansas, Delaware, Mississippi, New Jersey and Tennessee) have separate courts of equity, which are presided over by Chancellors. This is the old English idea, which prevailed there until the Judicature Act changed it in 1875 . Of interest is the fact that two of the States mentioned were original English Colonies, as well as the fact that three of the four others were admitted to the Union prior to 1826 , while Arkansas was admitted in 1836 . 
Seven States (Alabama, Connecticut, Georgia, Illinois, Indiana, Maine, Virginia and Wisconsin) have provision for separate courts co-equal with their courts of general jurisdiction, which are limited to certain counties or cities. For instance, Virginia has a corporation court for each incorporated city having a population over 5000 . Georgia may have a city court for any county seat of a county having a population of 10,000; Illinois has a Superior Court of eighteen judges for Cook County, and also twenty-two city courts in that many cities, besides its sixty-six courts of general jurisdiction.

Equally of interest is the widely varying number of inhabitants in each State to each judge-from one judge to every 8187 of population in Nevada, to one judge for every 137,893 of population in North Carolina, as will be seen by reference to Table II:

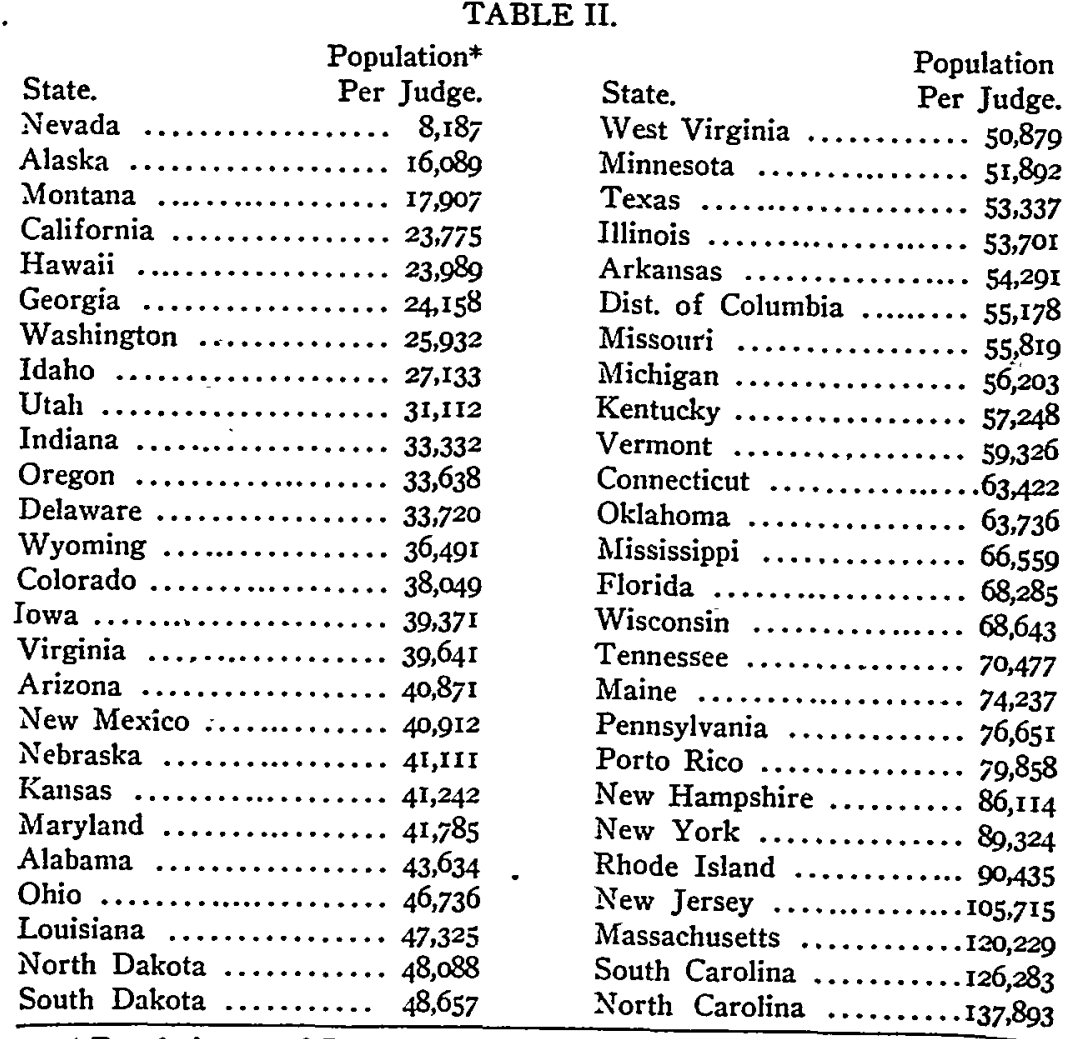

* Population as of June I, I9Io. Number of judges as of January I, I9I2. 
It should be mentioned that while South Carolina has a high proportion of population to its twelve judges, yet as its Constitution provides for the appointment of special judges to hold courts, the proportion is greatly lessened in practical operation.

In North Carolina the number of judges has not been increased since I90I, when four were added, but the North Car-olina Bar Association is now advocating an increase to twentyfour, while some urge that the number be placed at thirty-two. This last number would provide one judge for each 68,947 persons, which proportion would still be higher than that of fortyone other States.

The average population to each trial judge being 52,295, it is interesting to note that within a variation of 25 per cent. above and below that proportion (namely, between 39,225 and 65,369 ), will be found twenty-four of the States, there being fourteen which have a greater proportion and fourteen a lesser proportion. As the population of the United States increased 2 I per cent. in the decade I900 to I9ro, there should be allowed 4.25 per cent. on the above figures to approximate the rgI2 population, which will raise the average to 54,517 , or practically one trial judge for each 55,000 of population. This is very near the proportion existing in the District of Columbia.

It would be impracticable in an article like the present, to attempt to discuss the figures as to the several States in detail. Discussion will, therefore, be confined to a few observations on the number of trial judges in the States of New York and Pennsylvania.

\section{New York State.}

An analysis of the situation in New York State, in which there are one hundred and two judges of the Supreme Court (theoretically one for each 89,324 population), is of interest, as will be seen by the following table, giving the proportion of population for each judge:

As the nine districts of the Supreme Court are grouped into four departments for appellate division work, to which seven judges are assigined to the first and second departments (two are temporarily assigned to the second department, owing to increased work of that department), and five to the third and fourth departments, there are twenty-four Supreme Court judges taken out of 
actual trial work. This leaves only seventy-eight for trial work, which practically results in having one judge for every 116,837 of population-a proportion only exceeded by three other American States, namely, Massachusetts, South Carolina and North Carolina.

To show the present inequality of the burdens placed upon some of the judges, the following table showing the number of judges in the several districts, the present number assigned to the appellate division work, and the number remaining in each district for the regular trial work, and the proportion of population to each Supreme Court judge, as well as to each one provided for trial purposes is of interest:

TABLE III.

\begin{tabular}{|c|c|c|c|c|c|}
\hline \multirow[b]{3}{*}{ District. } & \multirow{3}{*}{$\begin{array}{l}\text { No. of } \\
\text { Judges. }\end{array}$} & & \multirow{2}{*}{\multicolumn{2}{|c|}{$\begin{array}{l}\text { Population } \\
\text { per Judge. }\end{array}$}} \\
\hline & & Appellate & Trial & & \\
\hline & & Work. & Work. & All. & Trial. \\
\hline $\begin{array}{l}1 \\
2\end{array}$ & $\begin{array}{l}31 \\
20\end{array}$ & 4 & $\begin{array}{l}27 \\
16\end{array}$ & 89,113 & 102,315 \\
\hline 3 & 6 & 1 & 5 & $\begin{array}{r}109,531 \\
86,541\end{array}$ & $\begin{array}{l}130,914 \\
103,840\end{array}$ \\
\hline 4 & 7 & 3 & 4 & 76,162 & 138,259 \\
\hline 5 & 8 & I & 7 & 72,963 & $83,95^{8}$ \\
\hline 6 & 6 & 3 & 3 & 67,275 & I34,550 \\
\hline 7 & 7 & 3 & 4 & 88,542 & 154,949 \\
\hline 8 & 12 & 4 & 8 & 77,914 & 116,872 \\
\hline 9 & 5 & I & 4 & $109,65 I$ & 137,064 \\
\hline & 102 & 24 & 78 & 89,324 & I 16,837 \\
\hline
\end{tabular}

The present Constitution (1894) of New York State provides that there may be one judge in Greater New York for each 80,000 population or fraction over 40,000 , and in the remainder of the State one judge for each 70,000 of population or fraction over 35,000 .

If this maximum of the State Constitution were carried into effect by the legislature, and the judges provided in accordance with these provisions, and the assignments to the appellate division remain as they are at present, then instead of the figures in Table III showing the varying proportion of trial judges actually in the several districts-from one judge to every 83,958 to as high as one judge to each 154,949 - the number would vary from one judge to every 64,906 to one judge to every 100,912 ; theoretically, one judge for each 70,102 , or an actual average for trial work of one for each 85,974 , as will be seen from table IV: 
TABLE IV.

$\begin{array}{lccccc} & & & & & \begin{array}{l}\text { Increase } \\ \text { Over }\end{array} \\ \text { District. by Constitution. } & \text { Appellate } & \text { Trial } & \text { Population } & \begin{array}{l}\text { Present } \\ \text { Work. }\end{array} & \begin{array}{c}\text { Work. } \\ \text { Wumber. }\end{array} \\ \text { I } & 34 & 4 & 30 & 92,084 & 3 \\ 2 & 27 & 4 & 23 & 95,244 & 7 \\ 3 & 9 & 1 & 8 & 64,906 & 3 \\ 4 & 9 & 3 & 6 & 92,173 & 2 \\ 5 & 10 & 1 & 9 & 65,300 & 2 \\ 6 & 7 & 3 & 4 & 100,912 & 1 \\ 7 & 10 & 3 & 7 & 88,542 & .3 \\ 8 & 15 & 4 & 11 & 84,997 & 3 \\ 9 & 9 & 1 & 8 & 68,532 & 4 \\ & 130 & 24 & 106 & 85,974 & 28\end{array}$

Greater New York has a population of $4,766,88_{3}$, of which 2,33 I,542 is in the Borough of Manhattan, which has thirty-one Supreme Court judges, while the remaining boroughs have eighteen; but as eight judges are assigned to the appellate division, only forty-one are left for trial purposes. This compares poorly with the State of Ohio, with only 238 more people, 45 per cent. of whom are rural, which has 102 judges. So, also, the States of Maine, New Hampshire, Vermont and Massachusetts, combined, have only I00,000 additional population and forty-nine trial judges; Texas, with 900,000 less population, has seventy-three judges; the States of Maryland, Virginia and West Virginia, with 90,000 less aggregate population, have 107 judges; while the three Pacific Coast States of. Washington, Oregon and California, with 550,000 less population, have 164 judges, or just four times the number of trial judges in Greater New York.

\section{Pennsylvania.}

Pennsylvania, with a population of 7,665 , I I I, has one hundred judges of general jurisdiction, or one for each $76,65 \mathrm{I}$ (which seems a liberal provision in comparison with eight other States), and also has an Orphans' Court in the ten largest counties, with sixteen Orphans' Court judges; but as this article relates only to trial judges, they are not included in these figures. This average, however, bears very unequally over the State, especially since Philadelphia County, with $\mathrm{I}, 549,008$ population, has fifteen judges, or one for each 103,267 , and Allegheny 
County (comprising Pittsburgh), with $1,018,463$ population, has twelve judges, or one for each 84,872 . The seventy-three judges for the remainder of the State, then, each represent an average of 69,830 citizens. If Philadelphia and Pittsburgh were provided with a judge for each 70,000 of population, then the former should have twenty-two and the latter fifteen. On January 3, I9I2, the Supreme Court of Pennsylvania upheld the constitutionality of a court of limited jurisdiction for Pittsburgh, and immediately there was talk of creating such a court for Philadelphia to relieve the crowded dockets of the Common Pleas Courts. It has been announced that the new court of limited jurisdiction will have eight judges, in order to relieve the congested Common Pleas dockets, and that the Pennsylvania Bar Association Committee will discuss the same in their meeting this year. Would not the creation of additional judges in the present courts of these two cities, in the same proportion as, and no greater than, judges are provided in the remaining sixty-five counties of that State, relieve the courts of those two cities, and enable litigants to get more prompt trials?

It has been stated that parties in Philadelphia courts are twelve to eighteen months in reaching jury trials after bringing their suits. To avoid just such delays, many suits, especially against the traction companies, are now brought in the adjoining counties, and some of these dockets are beginning to be congested on account of increased litigation.

The eight counties nearest Philadelphia have trial judges in the following proportions to their population:

TABLE V.

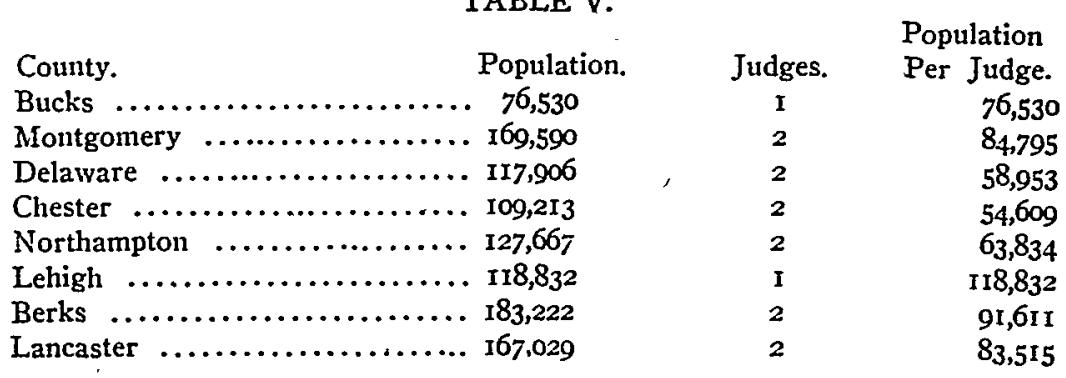

Three of these eight-Berks, Lancaster and Montgomery-have separate Orphans' Courts. 
Examining these figures and contrasting them with each other, it is very clear how much more liberal provision has been made for the judicial settling of disputed matters in these counties than in Philadelphia, where the ratio is one trial judge for each I03,267 of population. And the contrast becomes stronger when it is stated that from one-fourth to one-third of the population of Bucks, Montgomery and Delaware Counties transact business daily in Philadelphia. As a matter of fact, their large proportion of agricultural and residential population is not nearly. so given to litigation, as is a commercial and trading people like that of Philadelphia.

Those of us who bewail the methods and men of the present generation, when they are contrasted with a past generation, should be honest and accurate in statements of fact, for while glittering generalities are pleasant and generally carry weight, can the speaker vouch for the accuracy of that statement, and will he stand or fall by an investigation of the facts?

Today, so often, do we hear of the judges, mighty legal giants, of a past generation, and how they dispatched business, kept their dockets clear, and never allowed a litigant to be delayed, and that cases were brought to trial so soon after being brought.

When were those times? How many cases did the judges have to try? What was the population of their districts? And how many of that population were engaged in agriculture and other pursuits, which lead so seldom to litigations? A fair answer to some of these questions is shown in the following tables of Philadelphia and Allegheny Counties.

In former years the proportion of each judge to the population has been as follows:

TABLE VI.

Year.

1850

1860

1870

I 880

I 890

1900

I9IO
A. Philadelphia (County).

Population. 408,762

565,529

673,726

846,984

I, 046,964

I,293,697

I, 549,008
No. of Judges.

7

7

9

12

12

12

I5
Proportion. 58,395

80,761

73,747

70,582

87,247

107,808

103,267 


\begin{tabular}{lccr}
\multicolumn{5}{c}{ B. Pittsburgh (Allegheny County). } \\
Year. & $\begin{array}{l}\text { Population. } \\
\text { I880 }\end{array}$ & No. of Judges. & Proportion. \\
1890 & 335,759 & 6 & 59,293 \\
1900 & 551,959 & 6 & 91,993 \\
1910 & 775,058 & 9 & 86,117 \\
& $1,018,463$ & 12 & 84,872 \\
1880 & C. State of Pennsylvania & $($ entire) & \\
1890 & $4,282,891$ & 72 & 59,485 \\
1900 & $5,258,113$ & 80 & 67,635 \\
1910 & $6,302,115$ & 82 & 76,855 \\
& $7,665,111$ & 100 & 76,651
\end{tabular}

Philadelphia lacks only 25,000 of having as many people as the State of Arkansas, which has twenty-nine judges. It has nearly one-third the population of Ohio, which has seven times as many judges. Again, the combined population of Maryland and the District of Columbia only exceed it by 25,000 , and these two territorial divisions have thirty-seven judges to Philadelphia's fifteen; and the States of Maine, New Hampshire and Vermont lack 20,000 of equaling its population, yet they have nineteen judges.

But why further cite statistics from the past, for it is the present in which we live. Academically, the statistics are interesting; but the question of a sufficient number of trial judges to transact the business of the courts is a practical one, and must be met and considered, not in the light of the needs of the past, but of the present.

\section{Inferior Courts.}

Some persons argue for the creation of additional courts, local in their character and nature, combining all of the powers of a justice of the peace with some of the powers of a court of general jurisdiction, arguing that it would be less expensive and more convenient. They are variously called County, Municipal or Inferior Courts.

Eighteen States (including Hawaii Territory) have county or municipal courts, which combine the jurisdiction of the magistrate's court with some limited jurisdiction of the courts of general jurisdiction. In Colorado, Massachusetts and New York this jurisdiction is fixed at $\$ 2000$; in Connecticut, Illinois, Nebraska, Oklahoma, South Dakota and Texas, \$1000; in Florida, New Jersey, Oregon and Rhode Island, \$500; in Georgia and Hawaii, $\$ 300$; in Kentucky, \$200, and in New Hampshire, \$100. The 
eighteenth State is Wisconsin, and the jurisdiction given its county courts varies from one thousand dollars to five million dollars (Douglas County). In this article all of the Wisconsin courts having jurisdiction in civil cases over ten thousand dollars are counted as courts of general jurisdiction.

While these courts may work well in many States, the difficulty has been that generally litigants are not satisfied to have their matters determined finally by such inferior courts, and then follows an appeal to the court of general jurisdiction, and there results the expense of two trials instead of one.

Besides being on a plane with a justice of the peace in many matters, and only equal to the court of general jurisdiction in a few matters, and in all cases subject to its review, these courts are soon classed by the people as inferior courts, on the same level with the justice's court; and they avoid them when practicable, to go to the general trial court, for no court can be both flesh and fowl ; it must have a distinctive character.

\section{Other Jurisdictions.}

It is of interest to see how various State legislatures have provided judges for leading centers of their States, the proportions being figured out on the population of each county or judicial district and not alone on the city census. The following list of twenty-five cities, in twenty-two different States, all of which, excepting four (Dallas, Tex.; Houston, Tex.; Portland, Me., and Wilmington, Del.), had more than one hundred thousand population within their city limits in I9ro, shows a wide variation, just as do the several States:

TABLE VII.

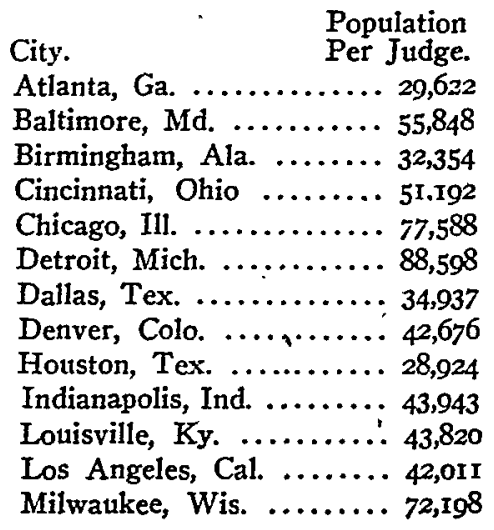

Population City. Per Judge. Minneapolis, Minn. ......47,640 New Orleans, La. ....... 48,439 Portland, Me. .......... 57,406 Portland, Ore. .......... 45,232 Pittsburgh, Pa. ......... 84,872

Richmond, Va. ........ 31,907

St. Paul, Minn. ......... 37,278

St. Louis, Mo. ......... 57,252

San Francisco, Cal. ...... 34,743

Seattle, Wash. .......... 31,626 Washington, D. C. ....... 55,178 Wilmington, Del. ....... 33,720 
Having considered how various commercial centers are supplied with trial judges, it is also of interest to note the situation in some cities bearing well-known geographical names, often referred to in the daily press, as follows:

TABLE VIII.

\begin{tabular}{|c|c|}
\hline $\begin{array}{l}\text { Population } \\
\text { Per Judge. }\end{array}$ & $\begin{array}{l}\text { Population } \\
\text { Per Judge. }\end{array}$ \\
\hline Annapolis, Md. ......... 29,531 & Lexington, $\mathrm{Ky} . \ldots \ldots \ldots \ldots 47,715$ \\
\hline Alexandria, Va. $\ldots \ldots \ldots, 36,725$ & Medicine Lodge, Kan. .... 49,206 \\
\hline Beaumont, Tex. ........ 19,09I & Ogden, Utah ........... 23,968 \\
\hline Breathitt County, Ky. . ... 49,208 & Ossowatomie, Kan. . \\
\hline Cripple Creek, Colo. ...... 27,76r & Oakland, Cal. ........... 4I,022 \\
\hline Calaveras County, Cal. .... $9,17 \mathrm{I}$ & Palm Beach, Fla. ....... 39,073 \\
\hline Deadwood, S. D. ....... 37,327 & Reno, Nev. ......... \\
\hline El Paso, Tex. ....... & Sioux Falls, S. D. .... \\
\hline French Lick, Ind. .... & Salt Lake City, Utah ..... 29,510 \\
\hline Hot Springs, Ark. ... & Tombstone, Arizona ..... 4I,49; \\
\hline Helena, Mont. ....... & Tonopah, Nev. ....... \\
\hline Kalamazoo, Mich. .... & Yuba City, Cal. ........ 6,326 \\
\hline $\begin{array}{l}\text { Leadville, Colo. ........ } \\
\text { Livingston, Mont. .... }\end{array}$ & Yuma, Arizona $\ldots \ldots \ldots \ldots \ldots 27,419$ \\
\hline & .........23, \\
\hline
\end{tabular}

Summarizing the question under discussion, it may be said that no uniform rule exists among the fifty-two separate jurisdictions, but that conditions everywhere sufficiently differ to require them to be settled in the light of the local surroundings, standards and ideals of the people among whom the courts are located.

Some of the States need additional judges, and are badly in need of them; others seem to be bountifully, perhaps too bountifully, supplied. California, as was seen in Table II, has one judge for each 23,775 of population, 40 per cent. of which is rural. Of the number of persons per judge, approximately 600 to $75^{\circ}$ are Chinese, and 150 are Indians; and estimating one male voter to every five of population, the State has one judge for every 4575 American male citizens (both foreign born and native), whether able-bodied or not. This seems to be too many trial judges to the population, and such an observation seems borne out by the fact that California is the first (and so far as the writer's knowledge extends, the only) American State to include her judges in the recall law recently adopted. The agita- 
tion for the recall of judges seems largely confined to the Western States, and among them, to those well up in Table II. The sudden change of sentiment among a very large number of the population of Los Angeles, early in December, I9I I, after certain developments in the trial of the dynamiting cases, shows the grave danger of the recall system to the fair and impartial administration of the law. If that change in opinion was for the better, the next one or more may, and probably will, be for the worse.

What proportion of population there should be to each trial judge can only be determined by the people of each community and State, as the State creates them. If her citizens are inadequately provided for in judicial facilities, it is her duty to remedy the defect, and likewise it is the duty of every citizen to help in the matter. Seven hundred years ago the Magna Charta of King John forever secured to the Anglo-Saxon people certain wellknown rights, therein enumerated, one of which was: "We will sell to no man, we will deny no man, or defer, right or justice," and that assurance is as sacred and valuable to the people of today as it ever was in the past.

Raleigh, N. C.

Alexander B. Andrews, Jr. 